\title{
JUSTIÇA CRIMINAL E CONDIÇÃO FEMININA NA CAPITAL DA REPÚBLICA EM MEADOS DO SÉCULO XX
}

\author{
Rivail Carvalho Rolim*
}

\begin{abstract}
Resumo: No início da década de 1940, em pleno regime do Estado Novo, uma nova ordem jurídico-penal foi implantada no país. A partir da planificação penal contida nesse código, o legalismo processual procurou encaminhar as situações de litigiosidade no interior dos tribunais. Nosso objetivo, neste artigo, é analisar como foram encaminhados os procedimentos judiciais em que mulheres foram denunciadas pelo poder judiciário por práticas abortivas.
\end{abstract}

Palavras-chave: cultura jurídico-penal, condição feminina, aborto.

Com o fim do regime militar e as promessas de mudanças que vieram em seu bojo, o debate acerca da noção dos direitos passou a ocupar a ordem do dia. Aliás, muitos desses significados representaram uma novidade na história recente, tendo em vista que houve uma ampliação do que deveria ser considerado como fazendo parte dos direitos dos cidadãos na sociedade brasileira.

Com essa nova configuração da sociedade brasileira, foi atribuída uma função importante ao poder judiciário no avanço da cidadania, mesmo tendo somente uma legislação simbólica ou "legislação álibi” (Neves, 1994). Isso porque as normas jurídicas

\footnotetext{
* Doutor em História Social pela Universidade Federal Fluminense (UFF); professor do Departamento de História da Universidade Estadual de Maringá (PR). Email: rivailrolim@hotmail.com

Pesquisa desenvolvida com apoio financeiro do CNPq.
}

Artigo recebido em 24 jul.2006 e aprovado em 3 ago. 2006. 
possuem um sentido promocional prospectivo, já que os direitos positivados pelo Estado podem ser atendidos ou efetivados (Vianna, 1997). Em função dessas mudanças é que, se em períodos anteriores as atenções estavam voltadas para o Executivo, na conjuntura atual, o terceiro poder da república passou a ser visto como de fundamental importância na conquista da igualdade definida pelas normas jurídicas.

Com esses novos termos de vivência social, vários segmentos que adquiriram maior visibilidade e formas de expressão nas últimas décadas - como negros, índios, mulheres, menores, adolescentes, idosos, homossexuais, meninos de rua, presidiários, sem-terra e sem-teto -, passaram a apresentar uma série de demandas ao poder judiciário. Entretanto, os tribunais espalhados pelas mais diferentes regiões do País tiveram um tratamento discriminatório em relação a essa agenda política e até mesmo certa incapacidade de acompanhar os processos mais inovadores de transformação social.

Diante dessa resistência do Judiciário, vários questionamentos passaram a ser feitos em relação a esse poder da República. Alguns pesquisadores começaram a empreender uma série de pesquisas para justamente entender os motivos que explicariam porque a sociedade brasileira tinha apresentado avanços significativos na conquista de alguns direitos sociais e políticos, mas quando se tratava do poder judiciário havia uma série de empecilhos (Adorno, 1994, 1995; Pandolfi, 1999; Pinheiro, 1991; Ribeiro, 1999). Tereza Caldeira (1991), por exemplo, ao tratar sobre a questão dos direitos humanos no País, lançou a proposição de que se tratava de um poder da República caracterizado por diferentes tradições e concepções, logo, possuía uma dinâmica distinta.

Apesar desses trabalhos apresentarem resultados significativos, pesquisas foram indicando que o descompasso entre o Poder Judiciário e os demais poderes da República, principalmente 
em relação à sua incapacidade de acompanhar as transformações políticas e sociais, não ficava circunscrito ao período de volta à normalidade institucional das últimas décadas (Adorno, 1988; Neder, 1995). Quando Caldeira se referiu às tradições e concepções, ficou claro que em outras conjunturas históricas estavam também presentes essas mesmas questões, revelando, com isso, um habitus na dinâmica do poder judiciário na trajetória histórica do País.

É justamente pensando nessas questões do tempo presente que voltamos nossa atenção para um período histórico - décadas de 1940-1960 - em que a sociedade brasileira vivenciou um intenso processo de urbanização, industrialização, modernização, mudanças de valores culturais e de grande efervescência de projetos políticos que resultaram na implantação de uma nova ordem jurídico-penal para administrar as situações de litigiosidade e o desenrolar das relações entre os indivíduos e os grupos sociais. João Manuel Cardoso de Mello e Fernando Novais (2006, p. 560) assim se reportam a esse período:

$\mathrm{Na}$ década de 50, alguns imaginavam até que estaríamos assistindo ao nascimento de uma nova civilização nos trópicos, que combinava a incorporação das conquistas materiais do capitalismo com a persistência dos traços de caráter que nos singularizavam como povo: a cordialidade, a criatividade, a tolerância.

$\mathrm{Na}$ realidade, o novo cenário social, que começava a ser configurado, se deparou com uma nova codificação penal - Código Penal (Decreto-Lei $n^{\circ} 2.848$, de 7 de dezembro de 1940), o Código de Processo Penal (Decreto-Lei no 3.688, de 3 de outubro de 1942) e a Lei de Contravenções Penais (Decreto-Lei $n^{\circ} 3.689$, de 3 de outubro de 1942), codificação esta que, salvo ligeiras modificações, continua até o tempo presente.

Logo que esse novo ordenamento jurídico-penal foi implantado, ele produziu uma série de efeitos legais na vida de 
inúmeros segmentos sociais que se envolveram em situações de litigiosidade e conflituosidade. Como destaca Louis Assier-Andrieu (2000), a prática jurídica tem a prerrogativa de atuar sobre a dinâmica social ao criminalizar condutas e comportamentos por intermédio da programação normativa contida na planificação penal.

Foi justamente com esse novo ordenamento jurídico-penal que as mulheres se depararam quando se viram envolvidas no legalismo processual, ao serem denunciadas pelo poder judiciário. Nosso objetivo é analisar a forma como a cultura jurídico-penal tratou as inúmeras mulheres acusadas de práticas abortivas na cidade do Rio de Janeiro, então capital da República.

Para o encaminhamento das reflexões, na primeira parte apontamos os principais postulados da cultura jurídico-penal presente nessa conjuntura, quando a sociedade brasileira alterou completamente sua ordem jurídico-penal. Como nosso intuito é o de apreender os desdobramentos legais do sistema jurídico em relação às mulheres que foram acusadas de práticas abortivas, na segunda parte analisamos alguns autos criminais de aborto.

\section{Idéias jurídico-penais na conjuntura da implantação do Código Penal de 1940}

Nas conjunturas em que ocorrem a estruturação e movimentação de novas normas jurídico-penais, as concepções filosóficas, as teorias jurídicas e os padrões socioculturais dos segmentos sociais envolvidos afloram com muita intensidade, pois, se a prática jurídica tem a função de regular a vivência social, logo afeta a vida das pessoas, seja no plano das idéias, seja na sua efetiva aplicabilidade. Conforme as palavras de Antonio Manuel de Hespanha (1978, p. 34), "a prática jurídica não se limita a transformar a consciência dos homens, mas produz transformações nas próprias relações sociais". 
Chamamos a atenção para essa questão tendo em vista que os princípios e postulados presentes no ordenamento jurídicopenal implantado no início da década de 1940 passaram a orientar as ações judiciais, ou seja, o trabalho dos operadores jurídicos no interior dos tribunais. Por conseguinte, é necessário não perder de vista que os processos criminais seguem um determinado rito processual, porque são conduzidos a partir da cultura jurídico-penal. Portanto, se fizermos uma análise das fontes criminais perdendo de vista esses aspectos, corremos o risco de ficarmos sem entender as noções jurídicas presentes nos autos criminais. Segundo Marc Bloch (2001, p. 131), nos países que seguem a tradição jurídica romanocanônica, a elaboração das regras de direito são "obra própria de um grupo de homens relativamente especializados e, nesse papel, suficientemente autônomo para possuir suas tradições próprias e, com freqüência, até uma lógica de raciocínio particular”.

Necessário salientar também que a prática jurídica não está liberta das pressões e dos constrangimentos sociais, ou seja, não há uma autonomia absoluta das idéias e das ações de seus operadores, apesar da existência de um habitus entre seus operadores, como salienta Pierre Bourdieu (1989). Georg Rusche e Otto Kirchheimer (2004), em um clássico trabalho produzido na década de 1930, já afirmavam que as teorias penais não podem ser explicadas somente a partir da lógica jurídica. Para esses pensadores da Escola de Frankfurt, as formas de punição têm uma estreita relação com a dinâmica social. Nesse caso, só é possível entendê-las observando os sistemas de punição concretos e as práticas penais específicas.

$\mathrm{Na}$ realidade, a massa documental pode ficar ininteligível se não houver uma compreensão das idéias formuladas pelo campo jurídico para o ordenamento social, ou seja, a cultura jurídico-penal que orienta a ação dos seus operadores. Para Antonio Manuel de Hespanha (1978, p. 33), a prática jurídica possui a prerrogativa de fazer uma "prévia valoração das condutas sociais levada a cabo 
pelo aparelho jurídico", logo, é fundamental entendermos a cultura jurídica que conduz as ações no interior do legalismo processual.

Como nos alicerçamos no pressuposto teórico-metodológico de que a prática jurídica só pode ser entendida quando cotejada com a dinâmica social, necessário ressaltar que nessa conjuntura em que foi aprovada a nova codificação penal houve uma reorganização dos termos da vivência social na sociedade brasileira. O Estado foi organizado para atuar de forma mais sistemática na regulação da dinâmica social realizando intervenções periódicas, quando não, elaborando estratégias para defender a sociedade.

Ao assumir o intervencionismo na ordem econômica em uma conjuntura de intensos conflitos em todo o mundo ocidental, o Estado abriu espaço também para que o sistema legal atuasse de forma mais sistemática sobre a dinâmica social. $\mathrm{O}$ argumento era de que o classicismo penal, produto do liberalismo e que fora instituído na conjuntura de consolidação da sociedade capitalista, início do século 19, era inadequado, tendo em vista que fora estruturado nos moldes do individualismo, com isso, não apresentava qualquer mecanismo de defesa da sociedade, do coletivo, do social. Nelson Hungria (1941, p. 266), um dos membros da comissão revisora do Código Penal de 1940, salientava que:

O Estado modelado na incude Revolução Francesa estava reduzido ao pouco edificante papel de um guarda noturno modorrento que só desperta a um rumor alto e se limita a soprar no seu apitado assustadiço e inócuo. Era o Estado negativo, era o Estado agnóstico, o Estado roi faineant. Enleado nas suas autolimitações, nem mesmo podia defender-se com êxito. A concepção filosófica dos direitos do homem, interpretada pela ortodoxia do demo-liberalismo, redunda numa permanente hostilidade do indivíduo contra o Estado. $\mathrm{O}$ Estado era o mal necessário, que devia ser contido dentro das mais estreitas lindes. 
Diante desse quadro sociopolítico, o campo jurídico-penal foi concebido como tendo um papel importante para gerir os novos princípios do ordenamento social, dito de outro modo, na atribuição dos direitos e deveres. O entendimento era de que o sistema jurídico poderia cumprir a função de regular as liberdades individuais e os interesses coletivos. Para os operadores jurídicos, com a implantação de um novo ordenamento jurídico-penal a sociedade brasileira estaria mais preparada para defender seus interesses, pois haveria um controle mais efetivo sobre a vida social.

As assertivas de Agamenon Magalhães (1941, p. 403), que chegou a ser interventor no Estado de Pernambuco, de que o "Estado para ser a ordem, o comando, a orientação, a disciplina, faz o direito, traça a conduta, impõe as normas de acordo com as circunstâncias", são bastante sintomáticas dessa cultura jurídico-política. Em trabalho anterior, chegamos à conclusão de que a cultura jurídico-penal do período em foco manteve

os princípios considerados inamovíveis para o campo da ciência penal, como a responsabilidade moral e a idéia de vontade culpável; contudo, considerava-se também que se deveria fazer observações acerca da pessoa do criminoso, não encarar o delito somente como entidade jurídica; da mesma forma, dever-se-ia ter um cuidado especial de observar e analisar os agentes sociais quando chegavam nas instâncias judiciais. (Rolim, 2004, p. 181).

No que diz respeito aos postulados da cultura jurídico-penal, com o avanço do positivismo penal, na virada do século 19 para o 20, passou-se a argumentar que era necessário observar não só o crime, mas também o criminoso. Para Marcos César Alvarez (2002, p. 679),

ao partir do pressuposto de que os comportamentos são biologicamente determinados, e ao basear suas afirmações em grande quantidade de dados antropométricos, Lombroso construiu uma teoria evolucionista, na qual os criminosos aparecem como 
tipos atávicos, ou seja, como indivíduos que reproduzem física e mentalmente as características primitivas do homem.

Se, por um lado, o positivismo penal do início do século 20 dava grande ênfase à existência de sinais físicos para definir o criminoso, por outro, abria espaço para se considerar o ambiente social como responsável pela geração de pessoas criminosas, pois havia o entendimento de que o meio provocava o enfraquecimento dos hábitos, a perpetuação dos vícios e das taras. Conforme as palavras de Michel Foucault (1996, p. 85):

A noção de periculosidade significa que o indivíduo deve ser considerado pela sociedade ao nível de suas virtualidades e não ao nível de seus atos; não ao nível das infrações efetivas a uma lei efetiva, mas das virtualidades de comportamentos que elas representam.

Para Cristina Rauter (2003, p. 60), esse discurso criminológico, por "prescindir totalmente da causa biológica na determinação da anormalidade do criminoso, abriu espaço para que a sociedade, especialmente no que diz respeito à família, pudesse ser vista como a grande produtora de criminalidade". Apesar de se dar grande publicidade às teorias lombrosianas, não se pode esquecer de que, na visão sociológica de Ferri, o ambiente social deveria ser levado em consideração para se entender as causas da criminalidade.

$\mathrm{Na}$ realidade, a codificação penal de 1940 não abandonou os postulados do positivismo penal, no entanto, ressaltava-se que não era mais possível admitir que as motivações dos criminosos, o animus delinquendi, a voluntas sceleris, fossem buscadas em elementos fisiológicos ou biológicos, tal qual fazia o positivismo penal. Aliás, em artigo produzido logo após a publicação da nova codificação penal, Nelson Hungria (1942, p. 23) faz duros ataques às teorias lombrosianas, ponderando que elas "são tudo hipóteses, conjeturas, inferências sem base na realidade, falsificações do método galileano para o encalço de fantasias, deixando apenas de 
manifesto a persistente indemonstrabilidade das causas genéticas do crime".

Portanto, o ordenamento jurídico-penal de 1940 inspirou-se tanto nos postulados de que era importante a materialidade do fato, ou seja, o crime em si, quanto no aspecto subjetivo que envolve a quebra da norma jurídica (Garcia, 1943). Para João Aurealiano (1948, p. 349), “elementos objetivos e subjetivos constituem a personalidade do homem delinqüente, as suas tendências, os seus antecedentes morais e psíquicos, assim como as modalidades que caracterizam o fato criminoso".

Como podemos perceber nas palavras desse operador jurídico, a concepção de crime não se refere somente à infração da lei, já que é necessário também levar em consideração o comportamento daquele que cometeu o ilícito, como seus vícios, seus hábitos. Para Cristina Rauter (2003, p. 69), a partir do Código Penal de 1940, cresceu a importância dos procedimentos destinados a diagnosticar, analisar e estudar a personalidade das pessoas envolvidas em situações de litigiosidade. Além disso, a criminologia produziu uma concepção de crime como se fosse produto de uma anormalidade social ou individual.

Com a pregnância na cultura jurídico-penal, além da materialidade do fato, os aspectos subjetivos da quebra da norma jurídica eram fundamentais na condução da dinâmica processual, e as mulheres foram alvo de grandes preocupações por parte dos operadores jurídicos, pois tiveram muito de seus comportamentos e atitudes regulados na nova ordem jurídico-penal. Permaneceu a concepção na cultura jurídico-penal de que controlar sua conduta seria uma forma de evitar conflitos que pudessem "perturbar" a sociedade. Para exemplificarmos, no Título VI, que se referia aos crimes contra os costumes, e no Título VII, que tratava sobre os crimes contra a família, nos deparamos com várias noções jurídicas 
(mulher honesta, mulher virgem, inexperiência ou justificável confiança) e inúmeras figuras penais (estupro, posse sexual mediante fraude, sedução, rapto violento mediante fraude, rapto consensual, infanticídio, aborto, aborto provocado pela gestante ou com seu consentimento, aborto provocado por terceiro, aborto necessário, aborto no caso de gravidez resultante de estupro) que refletem como a cultura jurídico-penal concebia a condição feminina no país. ${ }^{1}$

Na programação penal, o aborto foi tipificado como crime no título de crimes contra a pessoa, no capítulo dos crimes contra a vida. Portanto, foi igualado ao homicídio, ao infanticídio e mesmo ao induzimento ao suicídio, embora com penalidade diferenciada. ${ }^{2}$ Como podemos ver, a cultura jurídico-penal adotou como estratégia a criminalização do aborto, por conseguinte, atribuiu ao Estado o papel de impedir que tal prática fosse realizada através de uma política pública criminal/penal. Os argumentos eram de que se constituía em um problema social muito grave. Segundo Almeida Junior (1942), professor da Faculdade de Direito da Universidade de São Paulo, o aborto era uma prática que carecia de ser enfrentada com mais urgência do que o infanticídio.

A introdução do aborto legal ${ }^{3}$ em algumas situações foi a novidade trazida em relação ao ordenamento jurídico-penal implantado no início de regime republicano. ${ }^{4}$ Isto acabou gerando inúmeras polêmicas, principalmente com os segmentos religiosos, pois estes entendiam que estava sendo infringido o quinto mandamento: "Não matarás". Os intelectuais que gravitavam na órbita do cristianismo católico ressaltavam, ainda, que se estava atentando contra a concepção do pecado original, pois quando ocorria a junção no ventre materno de dois elementos reprodutores - espermatozóide e óvulo -, aquele ser tinha recebido a alma, portanto, estava passível à pena de um pecador. Logo, se houvesse o sacrifício da criatura durante a vida pré-natal, ela seria privada 
do batismo e, desse modo, impedida de ter acesso ao paraíso (Almeida Junior, 1942) .

Em uma Encíclica do Papa Pio XI (1930), escrita nessa conjuntura, que tratava justamente do matrimônio cristão, houve a reafirmação da proibição absoluta do aborto. Mostra clara de que a Igreja Católica envidava todos os esforços para impor a sua verdade sobre o aborto e não que isto fosse visto como um direito inalienável da mulher ao próprio corpo. Essa instituição e seus representantes entendiam que o aborto, em qualquer fase da gestação, era um crime, um assassinato, um pecado. Em função dessa tipificação penal, podemos salientar que a própria lei já representava uma violência, conforme assevera Walter Benjamin (1986), tendo em vista que procurava controlar o processo reprodutivo da mulher.

Em função dessa resistência em relação à legalização do aborto durante o processo de elaboração do novo ordenamento jurídicopenal, as mulheres passaram a encontrar enormes dificuldades em fazer valer seus direitos. Estamos nos referindo às exigências feitas pelos hospitais quanto ao Boletim de Ocorrência Policial, mesmo não estando previsto em lei, para atenderem aquelas mulheres que sofrem violência sexual e querem fazer o aborto. Evidência de que para entendermos a vivência de direitos, ou mais especificamente, a condição feminina na sociedade brasileira, não podemos ficar presos somente aos códigos. Como assinala Marc Bloch (2001, p. 131), para entendermos muitos aspectos da realidade social não basta "enumerar uns depois dos outros os artigos de um direito de família qualquer".

Estamos nos referindo à Igreja, dada a sua relevância na trajetória histórica do mundo ocidental, do número significativo de pessoas adeptas ao cristianismo católico na sociedade brasileira e, também, devido à participação significativa dessa instituição nos debates para a definição dos termos de vivência social e do 
ordenamento jurídico-penal nessa conjuntura que delimitamos para análise (Romano, 1979; Beozzo, 1987; Dias, 1996). Isso evidencia a força da Igreja Católica e o ideário religioso na sociedade brasileira no processo de elaboração do ordenamento jurídico-penal, implantado no início da década de 1940.

O ordenamento jurídico-penal produzido pela Igreja Católica durante a Idade Média, no qual foram criminalizados vários tipos de comportamentos, principalmente aqueles que diziam respeito à sexualidade e aos desejos, surtiu efeitos de longa duração. Tanto que a equiparação do abortamento intencional de um feto animado ao homicídio (si conceptum in utero quis per aborsum deleverit, homicida est) e de considerar como crime os meios utilizados pela mulher para tornar-se infecunda estavam presentes no direito canônico e se mantiveram nos ordenamentos jurídicos da modernidade (Batista, 2000, p. 221).

$\mathrm{Na}$ realidade, as culturas jurídicas ocidentais continuam alimentando em grande medida as ordens legais no tempo presente (Rolim, 2005). Os agentes sociais da modernidade não se dissociaram completamente dos períodos históricos anteriores, haja vista que permanecem apropriando-se das construções do passado para alicerçarem sua participação na dinâmica social da contemporaneidade. As últimas reflexões vêm demonstrando que temos que explorar os aspectos de rupturas e continuidades para conseguirmos compreender toda a complexidade que envolve as mudanças de um regime social e político para outro. Em relação ao direito canônico, por exemplo, "grande parte das leis medievais sobre o sexo segue firmemente integrada no direito, no pensamento e na prática dos tempos modernos", da mesma forma que "ainda dominam nossas vidas certos elementos importantes da doutrina medieval concernente ao sexo" (Brundage, 2000, p. 21).

Não é sem sentido que, na contemporaneidade, ainda há uma relação muito próxima entre crime e pecado e que os códigos 
jurídicos servem como estratégia para se operar um aperfeiçoamento espiritual ou moral das sociedades que seguem os princípios do cristianismo católico. James Brundage (2000, p. 243) apregoa que no processo de secularizar a lei sexual e matrimonial, os Estados modernos apropriaram-se de grande parte da doutrina canônica medieval, e, com isso, uma porção considerável desses postulados segue orientando a conduta dos indivíduos no mundo ocidental no tempo presente.

Sintomático nessas assertivas de James Brundage é o fato de Oscar Stevenson (1946), professor de Direito Penal na Universidade Católica, em meados da década de 1940, dar um enorme destaque ao direito canônico, afirmando que as idéias penais da modernidade sofreram radicais inovações durante a Idade Média por intervenção dos princípios cristãos. Realmente, é impossível tangenciarmos a influência desse ordenamento jurídico, pois a Concórdia dos Cânones Discordantes de Graciano, elaborada na conjuntura das reformas gregorianas, nos séculos XI e XII, "revolucionou o estudo do direito canônico e deu-lhe uma coerência intelectual", por conseguinte, "o livro de Graciano foi algo novo e com sua aparição podemos começar a falar, pela primeira vez, de direito canônico como uma ciência jurídica" (Brundage, 2000, p. 246).

Com as mudanças sociais em curso ao longo do século XIX, a Igreja Católica tratou de se posicionar em relação ao mundo moderno, justamente alicerçando-se nos padrões socioculturais da Idade Média, período histórico em que tinha hegemonia sobre os termos da vivência social e produziu um ordenamento jurídicopenal referenciado até o tempo presente. No conhecido movimento ultramontano, gestado ao longo do século XIX, essa instituição procurou, com seu discurso teológico-político, denunciar os valores da modernidade, como o monopólio do Estado sobre os termos da vivência social, a falta de autoridade, o desregramento dos costumes e a libertinagem. A sexualidade dissociada do aspecto reprodutivo e o 
aborto foram vistos como práticas incompatíveis com a convivência social. Como aponta Riolando Azzi (1993, p. 103), a Igreja via “as diversas modificações que estavam ocorrendo nos costumes como novas ocasiões de pecado, de desordem moral e desagregação social".

Desse modo, inúmeras formas de violência sexual que poderiam ser cometidas contra as mulheres apareceram tipificadas na parte que tratava sobre os costumes e a família, demonstrando que a preocupação principal não era com os direitos individuais, mas com a quebra de valores da sociedade (Corrêa, 1981; Bassanezi, 1997). Para exemplificarmos, o estupro foi tipificado como crime contra os costumes e não como uma violência cometida contra a mulher. $\mathrm{Na}$ realidade, manteve-se a imagem da mulher como se fosse uma Eva pecadora, que procurava seduzir o homem mediante a sexualidade (Azzi, 1993, p. 113).

Diante dessa cultura jurídico-penal e de uma conjuntura histórica caracterizada por mudanças significativas nos padrões socioculturais, muitas mulheres tiveram que se dirigir aos tribunais da capital da República para responderem pelas acusações de práticas abortivas. Por sua vez, os operadores jurídicos passaram a ter as suas ações orientadas pelos novos princípios introduzidos no novo ordenamento jurídico-penal. Princípios estes caracterizados por tratar o aborto como uma questão de política criminal/penal, condenando e culpabilizando de forma veemente tal prática e por uma cultura jurídico-penal que procurava observar comportamentos, hábitos e condutas.

A partir dessa cultura jurídico-penal, procuramos acompanhar como foram conduzidas as ações nos tribunais, os desdobramentos legais produzidos na vida daquelas mulheres que foram acusadas de práticas abortivas, bem como o habitus presente entre os operadores jurídicos para tratar com essas situações de litigiosidade. 


\section{Cultura jurídico-penal e condição feminina: os atos e os autos criminais de aborto}

$\mathrm{Na}$ análise dos processos criminais adotamos como metodologia a observação de indícios e pormenores, muitas vezes negligenciáveis, pois entendemos que isso poderia ser mais eficaz na revelação de aspectos significativos de uma realidade social vivida por inúmeras mulheres denunciadas pelo poder judiciário. Focamos nossa atenção nos processos com o intuito de apreender a experiência vivida, trazendo à tona, com isso, os dramas individuais, a intimidade, os segredos, bem como os efeitos legais produzidos pela cultura jurídico-penal na vida dessas mulheres.

Estamos nos alicerçando nas formulações teórico-metodológicas de Carlo Ginzburg (1989), para quem o paradigma indiciário pode nos "ajudar a sair dos incômodos da contraposição entre 'racionalismo' e 'irracionalismo', tendo em vista que concebemos de fundamental importância os detalhes secundários, as particularidades insignificantes, para se "captar uma realidade mais profunda, de outra forma inatingível". De um universo de 100 processos analisados, selecionamos aqueles que demonstravam a dificuldade do sistema jurídico de impedir a existência de práticas abortivas na capital da República. Com esta perspectiva de análise foi possível assinalarmos momentos, às vezes dramáticos, da vida de mulheres que moravam na capital da República, no período que vai do início da década de 1940 até o início dos anos 1960.

Começamos com um processo-crime em que uma moça fez queixa contra um rapaz e uma parteira por terem provocado aborto sem o seu consentimento (Proc. 14/1944). Diante dessa acusação inicial, ela foi indiciada no Art. 124 e o rapaz e a parteira nos Artigos 125 e 126. Pelas informações contidas no processo, tratava-se de uma mulher com 19 anos, solteira, órfã de pai e mãe, empregada doméstica, que residia na casa de seus patrões por não ter onde morar. 
A jovem que fez a denúncia envolveu-se com um rapaz de nacionalidade portuguesa, que entregava regularmente leite na casa de seus patrões. Pelas suas declarações, notamos que com o avanço do relacionamento, tiveram um envolvimento sexual. Quando foi questionada pelo Delegado sobre os motivos pelos quais não havia prestado queixa por crime de sedução, respondeu que já era maior de idade. A moça estava se referindo ao Art. 217 do Código Penal que prevê pena de dois a quatro anos de reclusão para os casos em que se seduz a mulher virgem, menor de dezoito anos e maior de quatorze, "aproveitando-se de sua inexperiência ou justificável confiança", para citarmos literalmente essa expressão ambígua da lei. Cabe salientar que esses processos são interrompidos quando há o casamento, não necessariamente com o acusado. ${ }^{5}$

Como podemos ver, esse não foi o caminho percorrido no relacionamento da empregada doméstica com o leiteiro. Pelos autos do processo, eles passaram a se encontrar com certa freqüência, inclusive em hotéis da cidade, o que resultou em uma gravidez. Segundo relato da moça, o namorado, ao saber disso, propôs que ela fosse "procurar uma parteira a fim de se livrar do filho". Em um segundo momento, o próprio rapaz conduziu a moça para uma clínica clandestina (Proc. 14/1944).

Pelo depoimento, podemos deduzir sob que condição o aborto foi realizado na referida clínica clandestina. O preço combinado foi de Cr\$ 500,00, valor pago pelo rapaz. A moça foi andando até o local em que o trabalho foi realizado. Foi usado ferro para a extração do feto, permanecendo no consultório por 24 horas para que pudesse se restabelecer da intervenção. Podemos inferir que houve seqüelas, pois seis meses depois do episódio a moça declarou ao delegado que ainda estava se sentindo mal.

Pelas declarações, podemos perceber que fez a denúncia após realizar o aborto porque foi abandonada. Aliás, ressaltou, em 
um dos depoimentos, que a única pessoa que falou com ela foi a parteira. Vendo-se em uma situação difícil, contou a um irmão sobre o ocorrido; em seguida, também comunicou o fato a seus patrões que aparecem inclusive no processo, confirmando a versão dos acontecimentos.

As peças processuais produzidas a partir da denúncia inicial são significativas para entendermos como a moça, que foi submetida a uma situação aviltante e violentadora, teve que negar que fizera o aborto. $\mathrm{O}$ auto de exame de corpo delito, por exemplo, não foi conclusivo acerca das circunstâncias, devido ao tempo decorrido para a perícia, mais de quatro meses, e a data da gravidez alegada, dois meses. Diante disso, só ficou sendo válida a declaração da moça de que tinha feito aborto, mas nada que pudesse comprovar as circunstâncias em que foi realizado.

Em seu depoimento na delegacia, o rapaz disse que conhecia a moça somente de vista, porque ela "costumava passar pelo seu estabelecimento". Negou todas as acusações feitas, tanto com referência a ter mantido relações sexuais, como de ter "mandado que ela procurasse uma parteira". Acrescentou ainda que não conhecia a parteira que estava indiciada no processo, muito menos a gravidez. Para desqualificar o depoimento da acusação, disse que um conhecido seu é que teve relações sexuais com a moça, pois lhe confidenciou isso quando viu cumprimentando-a. Sintomática essa linha de defesa do rapaz, haja vista que "a virgindade física permaneceu como um dos componentes da honestidade feminina que a lei protegia" (Caulfield, 1996, p. 167).

No depoimento fornecido pela parteira, podemos ver mais claramente como a moça foi ficando em uma situação isolada da acusação do crime de aborto. Declarou que possuía consultório licenciado, atendendo clientes que eram assistidos por médicos. Todavia, não poderia precisar se recebeu a queixosa em seu 
consultório, muito menos ainda que tenha praticado qualquer intervenção. Nas investigações, os policiais não encontraram qualquer registro que comprovasse que a moça havia estado no consultório. Bastante sintomático, tendo em vista que dificilmente essas pessoas guardariam documentos que comprovassem uma prática tipificada como crime.

Com o andamento do processo, o advogado do leiteiro passou a acusar a moça por diferentes motivos. Alegava que ela havia feito a denúncia "por uma paixão desvairada, julgando-se vingar" do acusado e que o processo tinha lhe trazido "muitas lágrimas, muitos dissabores, como castigo divino da sua leviandade". Observamos que o operador jurídico recorreu a noções do ideário religioso em sua estratégia de defesa, demonstrando, assim, a não separação entre Estado e Igreja no interior da cultura jurídico-penal. Foi assinalado ainda que a acusação de que tinha sido deflorada pelo acusado, alegando ser menor, não fora verdadeira, pois foi "provado" que havia se envolvido com outro rapaz. Segundo a defesa, ficou evidenciado que "não tinha passado de honra", por isso, "não merecia o nome ou o amparo de um homem de bem".

Diante de uma situação em que todos conseguiram "provar" através de seus depoimentos que não tiveram nada a ver com o episódio, em juízo a moça negou que tivesse feito o aborto. Como em outros casos consultados, declarou que havia sofrido uma queda e isto foi o suficiente para encerrar o processo, inocentando todas as partes envolvidas. O rapaz, com uma simples declaração de que não conhecia aquela que lhe acusava, aliada à acusação de que a moça não tinha um "passado de honra", e a parteira, por dizer que não tinha muita certeza de que atendera alguém com aquelas características, foi suficiente para absolvê-los. Quando os elementos subjetivos foram considerados, os antecedentes morais e psíquicos foram utilizados para desqualificar a acusação e não para delinear o perfil dos acusados. A tese de defesa foi a de ressaltar que a moça 
não tinha bons antecedentes, já que tomara algumas atitudes que a desabonavam.

Chama a atenção nesse processo também o fato de que a parteira foi acusada pela mesma prática em uma delegacia de menores, mas foi absolvida. Em juízo, por exemplo, declarou que, de fato, foi denunciada pelos mesmos crimes, mas que não fora condenada em nenhum deles, indício claro de que poderia ter feitos outros abortos nas condições que descrevemos anteriormente, mas o sistema judiciário, apesar de tipificar o aborto como crime, não conseguia coibir a ação das clínicas clandestinas de aborto. Mostras claras de que as ações policiais e judiciais não estavam surtindo efeito em controlar um mundo clandestino.

Um outro processo que selecionamos possui novos elementos acerca de como se estabeleciam as relações nesse ambiente a que diferentes mulheres, pertencentes às classes populares, se dirigiam para fazer aborto. Novamente o episódio refere-se a uma moça que estava grávida do namorado e foi conduzida por ele a um médico, que por sua vez indicou uma parteira. O tutor da moça fez a denúncia (Proc. 339/1957).

Nesse processo, nos deparamos com uma moça de dezoito anos, nascida no interior de Minas Gerais e pertencente a uma família de onze irmãos. Ela viveu em companhia dos pais naturais até os onze anos. No início da década de 1950, mudou-se juntamente com a irmã para o Rio de Janeiro, passando a viver na residência de um casal, trabalhando como doméstica. Chama a atenção o fato de que os cônjuges não possuíam grau de parentesco com as duas menores, mas ficaram com a guarda judicial. Aliás, isto foi feito por um juiz da cidade de Ibiá, Estado de Minas Gerais. Talvez seja mais um daqueles casos em que os pais, vivendo em uma situação de extrema dificuldade no interior de Minas Gerais, se viram na obrigação de 
permitir que suas filhas fossem morar na capital da República, com a esperança que tivessem uma vida melhor.

A moça conheceu um rapaz, que aparece indiciado nesse processo, passando a namorá-lo desde o primeiro encontro, ocorrido na Quinta da Boa Vista. Com o decorrer do relacionamento, passaram a freqüentar um hotel no centro da cidade. Depois de sete meses de relacionamento, acabou ficando grávida. Ao tomar conhecimento da situação, o rapaz passou a dar vários tipos de remédios para a moça, como injeções e o conhecido Regulador Xavier, mas isso não interrompeu a gravidez.

Diante da situação vivida pelo casal de namorados, iniciaram um périplo pelos "profissionais" para que pudessem, de alguma forma, "resolver" o problema da gravidez indesejada. Pelo depoimento prestado pela indiciada, o namorado levou-a em um médico para se certificarem da gravidez. Ao ficar comprovado, foi orientada a procurar um outro médico, o qual, por sua vez, indicou uma parteira.

Novamente, nos deparamos com uma situação em que uma jovem se encaminhou para um local clandestino. Pelas declarações contidas no processo, foi submetida a uma intervenção cirúrgica em que a parteira, após lhe aplicar um anestésico, "fez o aborto por meio de ferros", conforme consta nos autos do processo. Declarou ainda que sentiu muitas dores, como se não tivesse sido anestesiada. Em seguida foi para casa e começou a tomar os remédios Leite de Magnésia, Dibiotil e Cibalena, receitados pela parteira.

Daí em diante teve início o processo de indiciamento de todas as pessoas envolvidas no episódio. No decorrer dos depoimentos, todos negaram peremptoriamente que tivessem tido qualquer participação, menos a moça, já que a queixa crime era em decorrência de sua notificação às autoridades. O laudo pericial só comprovou que o aborto havia sido realizado por instrumento cirúrgico. A 
receita que poderia demonstrar o envolvimento da parteira no episódio apresentou um resultado não conclusivo quando submetido ao exame grafotécnico.

O rapaz indiciado, por exemplo, admitiu a existência do namoro, contudo, fez um depoimento em que evidenciou determinados aspectos do comportamento da moça. Disse, por exemplo, que quando iniciou o relacionamento ficou até surpreso, pois ela "mostrou-se mais arrebatada, roçando-se muito nele, dando margem para que a convidasse para manter relações sexuais, e maior foi seu espanto quando obteve o assentimento dela". Acrescentou ainda que conseguiu com que ela lhe "confessasse ser mulher feita" e que isto ficou mais evidente quando "durante o coito mostrouse com bastante prática". Depois disso, só veio a encontrá-la após cinco meses, quando já passeava com a namorada. A estratégia de defesa foi a de ressaltar que a moça não era uma "mulher honesta", denominação, inclusive, presente no ordenamento jurídico-penal. ${ }^{6}$

Na seqüência, o rapaz aparece como o "bom conselheiro", o “cumpridor da lei”. Disse que até aconselhou a moça a comunicar seus pais adotivos de que estava grávida, inclusive, alertando-a dos perigos que corria quando esta lhe pediu para levá-la em uma parteira. Terminou afirmando que não a encaminhou para nenhum médico, muito menos a uma parteira, e que estava até "surpreendido que a moça consentira em fazer o aborto".

Com essa linha de depoimento, orientado pelo advogado, o rapaz se distanciava completamente da moça que confessara na delegacia que tinha feito um aborto. Da mesma forma, eliminava a possibilidade de que tivesse estabelecido algum tipo de contato com as pessoas envolvidas. Essa versão foi reforçada com o depoimento dos médicos. Um deles, por exemplo, disse que não tinha "a menor lembrança da moça". O outro, que não se recordava de ter atendido alguém com aquele nome. O médico salientou ainda que "não seria 
leviano a ponto de indicar algum fazedor de anjos" e que conhecia de nome a parteira, mas não sabia que a mesma era dada a tais práticas.

Chama a atenção a expressão fazedor de anjos. É um indício claro de que havia uma denominação no imaginário social para referirse às práticas abortivas. Salientamos que as idéias não aparecem sem terem certa pregnância na vida social, ou seja, não estão descarnadas da realidade. Ademais, a existência dessa expressão demonstra o sintoma de uma prática que fazia parte do cotidiano das mulheres que moravam na capital da República.

A expressão fazedor de anjos faz também uma clara referência ao ideário religioso, pois tal prática é vista como responsável por enviar crianças mortas para o céu. Carrega latente o postulado do direito canônico, alvo de defesa sistemática dos intelectuais do cristianismo católico que participaram dos debates para a elaboração do Código Penal de 1940 de culpabilizar/condenar a prática do aborto.

Sobre a parteira, vale destacarmos que também negou que tivesse mantido algum tipo de contato com a moça, muito menos que havia praticado aborto. Entretanto, em sua ficha criminal constam outros processos pela mesma prática. Para reforçar sua defesa, arrolou vários médicos como testemunhas. Grosso modo, afirmaram que conheciam-na havia muito tempo e que poderiam dizer que exercia "sua profissão com competência, que é uma profissional que merece o melhor conceito". Com essa linha de defesa, os advogados procuraram assinalar que a indiciada era uma "pessoa de bem", que seria incapaz de fazer aborto em alguém, pois isto atentava contra seus "valores morais".

$\mathrm{Na}$ estratégia de inocentar a indiciada, o operador jurídico acabou reforçando o processo de condenação do aborto, pois ao mesmo tempo em que procurava mostrar que sua cliente não estava 
envolvida, culpabilizava intensamente tal prática. A estratégia da defesa foi conduzida no sentido de reforçar que "pessoas de bem" jamais se envolvem com práticas altamente condenadas pela sociedade, principalmente o aborto, já que é responsável justamente em enviar "anjos para o céu". Como podemos ver, os operadores jurídicos condenavam com muita veemência, apelando, inclusive, para suas convicções religiosas.

Nos procedimentos judiciais, havia uma clara intenção de ressaltar que a acusação de a parteira estar cometendo um crime era infundada, pois se tratava de uma mulher que possuía uma "vida exemplar", inclusive como profissional. Diante dessa situação, os advogados de defesa desqualificaram a acusação, argumentando que a moça possuía uma trajetória de vida que não lhe permitia provar que tinha uma vida "tão exemplar" quanto a mulher a quem acusava.

$\mathrm{Na}$ realidade, tratava-se de um processo em que uma moça oriunda das classes populares estava acusando de aborto uma parteira, membro de um grupo socioprofissional composto, em sua grande maioria, por pessoas de um nível social mais elevado. Diante dessa assimetria na condição social e da rede de proteção criada para proteger a parteira, a tese de defesa foi que a acusação não tinha fundamento, que as palavras da querelante não eram confiáveis. $\mathrm{Ou}$ seja, a moça não tinha dignidade para acusar um "bem nascido", pois pertencia a um segmento tido como possuidor de vícios morais decorrentes da sua condição de vida (Cardia, 1995; Opotow, 1990). Como alega Cristina Rauter (2003, p. 61), a cultura jurídico-penal concebia que a pobreza gerava o enfraquecimento dos hábitos, levando a uma anomalia moral.

Notamos claramente que as testemunhas da parteira prestaram seus depoimentos no sentido de proteger a pessoa com quem tinham uma relação de proximidade. Podemos entrever que havia um 
código de conduta que se manifestava de maneira silenciosa, quando exposto a essas situações de tensão. Como o grupo socioprofissional estava em "perigo", foi construída uma rede de proteção para que não fossem considerados partícipes do funcionamento de uma rede clandestina de clínicas de aborto. Tratava-se, sobretudo, de relações de cumplicidade, de gerir ações visando estabelecer um controle e um domínio sobre aquele mundo que funcionava nos subterrâneos.

$\mathrm{Na}$ seqüência do processo, vendo-se diante de uma situação em que iria ser a única acusada, a moça mudou o depoimento, dizendo que abortou porque havia levado uma queda, provocando uma forte hemorragia. O advogado, por sua vez, passou a defender seu cliente com a tese de que a denunciante havia sido vítima do casal de tutores, que queriam forçar o casamento. Acrescentou ainda que seria a forma deles se livrarem do ônus de ter que sustentar a filha adotiva. $\mathrm{O}$ advogado ressaltou que a querelante "comprometida e coata, teria que se prestar à execução do diabólico plano do casal com quem, à época, residia”. Diante desses argumentos e com a moça mudando o depoimento, o Ministério Público não ofereceu denúncia.

Em um outro processo que analisamos, o segmento social dos "bem nascidos" procurou resolver o "problema" criado pelo filho menor que engravidou uma adolescente, que trabalhava na casa como empregada doméstica. Foram denunciados o pai do garoto e o médico apontado como o responsável por fazer o aborto. Os pais da garota é que fizeram a denúncia (Proc. 900/1959) .

No depoimento dos pais, constatamos que se tratava de uma adolescente oriunda das classes populares, pois era filha de um lavrador, que morava próximo a Petrópolis, em uma área rural. A filha do casal fora para o Rio de Janeiro, passando a trabalhar como doméstica na casa do médico, que morava na área central da cidade. Logo que chegou, começou a ser assediada pelo adolescente. 
Desse relacionamento, a adolescente acabou ficando grávida. Para resolver a situação do filho, o médico levou-a ao consultório de um colega de profissão, que aparece indiciado. Segundo o pai da adolescente, quando chegou ao local, o médico provocou aborto em sua filha "mediante a aplicação de uma injeção na altura do umbigo". Em seguida, ela foi encaminhada para a chácara de uma parteira, para que pudesse se restabelecer. Todas as informações foram confirmadas pelo irmão da denunciante, pois em várias ocasiões acompanhou a irmã nas idas ao médico e à casa da parteira, em um lugar afastado do centro da cidade.

Apesar da denúncia feita de forma bem minuciosa, em nenhum momento foi possível mostrar que o médico, a parteira e o pai do adolescente, que também era médico, estavam envolvidos no episódio. O depoimento do médico indiciado foi de que nunca vira a adolescente, que não constava em seus registros que havia atendido alguém com aquelas características. O médico, pai do adolescente, declarou que era uma coisa fantasiosa da adolescente, talvez influenciada pelo irmão mais velho. Disse ainda que a família tentara até lhe extorquir dinheiro. A parteira declarou que a adolescente foi para a sua casa para trabalhar e não para se recuperar de um suposto aborto que havia feito. Não houve qualquer questionamento nos autos criminais sobre o curto período de tempo que a adolescente morou na casa da acusada, supostamente trabalhando.

No desfecho do processo, os dois médicos foram inocentados, pois nem os laudos periciais foram conclusivos, nem os depoimentos suficientes para demonstrar claramente o que havia acontecido. Portanto, estamos diante de um episódio em que uma adolescente foi submetida a uma realidade social violentadora, porque realizou o aborto em uma situação de clandestinidade sem o conhecimento de seus pais naturais e com grande intimidação da família onde trabalhava como empregada doméstica. 
Aqui vemos como se articularam as peças de defesa dos médicos e da parteira. Para os advogados, as acusações não tinham fundamento, porque seus clientes possuíam uma "vida ilibada", e principalmente porque eram profissionais respeitados na cidade do Rio de Janeiro. Nas peças processuais, fica evidente que os argumentos foram no sentido de ressaltar que seria "inconcebível" que pessoas pertencentes ao segmento social dos "bem nascidos", "moralmente inatacáveis" tivessem levado uma adolescente para fazer aborto. Repete-se a idéia de que tal prática atentava contra os princípios morais e que famílias respeitáveis jamais realizariam algo tão condenável pela sociedade.

Selecionamos um outro processo em que fica evidente que o sistema jurídico-penal não conseguiu responsabilizarnenhuma pessoa pela morte de uma mulher submetida a uma prática abortiva em uma clínica clandestina (Proc. 1732/1964). Estamos evidenciando isto, pois o Código Penal de 1940 previu severas punições para aqueles que estivessem envolvidos em práticas abortivas, no entanto, quando isto, de fato, ocorreu, não houve mecanismos para coibir esse tipo de prática. Em outras palavras, tal prática foi tipificada como crime, mas quando isto chegou ao legalismo processual, não redundou em punições.

No processo, a acusação ficou ainda mais difícil, pois as versões do episódio foram dadas pelo marido da vítima, pela parteira e pelos vizinhos que acompanharam o sofrimento da mulher ao levaremna ao Hospital Carlos Chagas, quando perceberam que estava com tétano, ocasionado pelas complicações do aborto que havia feito.

A mulher, que veio a falecer depois de ter realizado o aborto, morava no bairro de Realengo e tinha dois filhos. Estava casada havia cinco anos, seu marido era natural do Estado de Pernambuco e estava desempregado. Quanto à condição de vida dessas pessoas, cabe assinalar que provavelmente faziam parte dos vários grupos de 
migrantes nordestinos que se dirigiram ao Rio de Janeiro naquela conjuntura, mas que não encontravam emprego. Na realidade, esses segmentos sociais não encontravam oportunidade de trabalho estável, oscilavam entre o desemprego e o subemprego. Ao procurarem as cidades em busca de melhoria das condições de vida, em sua maior parte, fixaram-se onde e como puderam no cenário urbano.

Para termos uma idéia desse quadro social no Rio de Janeiro, dos 405.999 prédios existentes na cidade em 1950, 44.621 eram barracos em favelas. Dos 94.000 prédios construídos entre 1940 e 1949, 24.000 eram barracos (Lobo, 1992). Diante dessa realidade, foram elaboradas as teorias sobre a marginalidade social que, entre outras coisas, consideravam que essas famílias tinham dificuldades de ajustamento social e psicológico, tinham uma vida desorganizada, e, por conseguinte, completamente alheias aos valores da vida moderna (Kowarick, 1975; Neder, 1994). Nesse episódio, estamos justamente tratando de um casal cuja esposa manifestou interesse em fazer o aborto porque tinha arrumado emprego de enfermeira no Hospital de Tuberculosos de Bangu, mas como estava grávida, não teve condições de aceitá-lo (Proc. 1732/1964). Como podemos apreender, a mulher também participava na composição da renda familiar, e, no momento, para agravar ainda mais a situação, o marido estava desempregado.

Depois de apurar que a mulher havia morrido por complicações em práticas abortivas, a promotoria ofereceu denúncia contra a parteira. A indiciada negou veementemente as acusações, embora constasse em sua ficha criminal outros processos com as mesmas denúncias. Foi constatado rapidamente que a mulher havia falecido por complicações no aborto a que fora submetida. Entretanto, em uma outra parte do processo nos deparamos com versões completamente divergentes acerca do episódio. Segundo o marido, sua esposa tinha se dirigido à casa da parteira para fazer o aborto e que ele veio a saber do episódio porque ela o confidenciou a uma vizinha, aliás, 
a mesma mulher que a encaminhara ao Hospital. Além disso, diz também que sentiu falta de uma aliança, de uma medalha com cordão e de outras jóias que pertenciam a sua esposa. Apesar de fazer essas acusações, no próprio depoimento admitiu que em sua casa havia uma sonda de borracha. Provavelmente a mulher tentara fazer o aborto em sua casa, demonstração do desespero ao ver que poderia perder o emprego em função da gravidez.

Em depoimento, a parteira disse que conhecia a vítima porque fizeram várias viagens de trem juntas. Além disso, era conhecida na vizinhança em razão da função que exercia, a de executar trabalhos de parto, mas que, naquele caso, não havia sido procurada pela vítima para fazer o aborto. Vale ressaltar que, na casa da parteira, foram encontrados vários objetos pertencentes à mulher que veio a falecer vítima de tétano. A versão apresentada para a existência desses objetos é de que a mulher vinha se queixando do marido, pois o mesmo era "dado à malandragem, deixando-a em casa passando privações, juntamente com dois filhinhos ainda em pouca idade, estando ditas criancinhas muito doentes e sem qualquer assistência médica; após tais lamentos, a vítima pediu que lhe emprestasse dinheiro". Ainda conforme a acusada, a mulher ficou de pagá-la no final do mês, pois receberia um montepio, dando as jóias como garantia do empréstimo. As investigações policiais não foram conclusivas no sentido de apontar se as jóias haviam sido utilizadas para fazer o pagamento pela prática do aborto ou para quitar o empréstimo.

A partir dessas versões constantes no processo, a parteira foi indiciada por "provocar aborto, sem o consentimento da gestante", sendo o crime agravado por ter provocado a morte da vítima. No relatório, o delegado ressaltou que "refere-se estes autos a mais um dos delitos que ferem de perto a dignidade humana, onde a figura de uma mulher inescrupulosa surge como autora do ilícito penal". $\mathrm{O}$ representante do poder judiciário destacou ainda que era uma 
"criminosa fria que faz do crime fonte de renda". Procurou alicerçar mais a acusação, enfatizando que o aborto havia provocado a morte da vítima, que, por sua vez, tinha deixado "no mundo, à mercê da sorte, dois outros inocentes". Apesar da contundência das acusações, no próprio relatório, o delegado apontou que "as provas testemunhais são um tanto fracas" para, de fato, comprovar que a parteira fez o aborto na mulher.

A defesa foi baseada na tese de que a denúncia era improcedente. O advogado atribuiu isso a uma "acusação leviana, partida de um cidadão inescrupuloso, que encontrou, para as suas infundadas acusações, guarida por parte das autoridades distritais". Chama a atenção que se a acusação recaía sobre a parteira, o advogado passou a acusar o marido da vítima nos seguintes termos:

Não resta a menor dúvida de que este sabe perfeitamente quem praticara o aborto em sua mulher do qual decorreu a morte da mesma, e não declara seu nome todavia, porque estaria fatalmente implicado, visto pelos dois depoimentos puros e sinceros de seus inquilinos, se depreende perfeitamente que ele sabia que sua mulher se submetera com seu consentimento à prática de melindrosa operação, qual seja, o aborto, do qual decorreu a morte da paciente. (Proc. 1732/ 1964).

Diante dessa troca de acusações e do fato de que as autoridades policiais não tiveram muita certeza sobre as circunstâncias em que ocorreu o aborto, pois segundo o próprio delegado essa "intervenção criminosa teria se verificado intramurus, em ambiente impróprio e despido de qualquer higiene", não ofereceu uma denúncia mais consubstanciada. Embora o delegado esteja se referindo à clínica clandestina, devemos enfatizar que se a mulher tivesse, de fato, feito o aborto em sua casa com a sonda de borracha, também estaria exposta às mesmas condições degradantes. Na realidade, a criminalização do aborto, a condenação e a culpabilização pública forçaram essas 
mulheres a tentar resolver a questão da gravidez indesejada em lugares isolados, distantes dos olhos alheios. O resultado foi que o marido e a parteira foram absolvidos e mais uma vida se foi, ficando a sensação de que a vítima é que fora punida com a morte.

\section{Considerações finais}

Ao analisarmos esses processos, ficou evidenciado que as mulheres que fizeram abortos pelos mais diversos motivos tiveram que recorrer a um mundo que funcionava sem qualquer tipo de controle por parte do aparato público, apesar do postulado de que o Estado tivesse de atuar de forma mais sistemática sobre a dinâmica social, com medidas policiais e judiciais, para que pudesse criar um sistema de defesa da sociedade contra as práticas ilícitas.

Não tendo respaldo legal, já que o Código Penal preceituava o aborto como crime, inúmeras mulheres foram submetidas a intervenções em ambientes completamente inapropriados para o atendimento e, não sendo concebido como uma medida de saúde pública, mas criminal e penal, elas ficaram à mercê dessa situação cruel e violentadora. Os exemplos analisados são mostras claras de que a criminalização do aborto no Código Penal de 1940 não surtia os efeitos necessários para impedir que as práticas abortivas continuassem sendo realizadas na capital da República, nos anos dourados. Na realidade, o sistema judiciário não conseguia impedir o funcionamento dessas clínicas clandestinas, apesar das práticas abortivas constarem na planificação penal. Aqui podemos recorrer às palavras de Raul Zaffaroni (2001, p. 19) de que o discurso jurídicopenal da legalidade "engana, ilude e alucina", pois se refugia e se isola no "dever ser", nunca considerando o "ser", qual seja, a realidade vivida por inúmeras mulheres das classes populares na capital da República. 
Nos episódios que analisamos, as mulheres tiveram que ser socorridas nos hospitais logo após o aborto devido às complicações ocorridas, evidenciando que ao adentrarem nessa rede clandestina, as possibilidades de seqüelas físicas, para não citarmos as psicológicas, faziam parte do cotidiano. O sistema jurídico se chocava frontalmente com a realidade social, à medida que, ao mesmo tempo em que havia criminalizado o aborto, no interior dos tribunais não oferecia qualquer mecanismo que pudesse conter esse mundo clandestino que oferecia seus "serviços" na Capital Federal.

Cabe salientarmos ainda que as mulheres que chegavam aos tribunais, acusadas de fazerem abortos, eram pertencentes às classes populares, como podemos verificar nos processos analisados. Suas denúncias eram rapidamente demolidas nas peças processuais, mesmo com fortes indícios de que havia uma rede clandestina de clínicas de aborto na capital da República no período em que focamos para a análise. Em suma, a forma como o Estado brasileiro lidou com a gravidez indesejada nos marcos desta pesquisa foi por intermédio de uma política criminal, que apresentava sinais claros de que não dava conta de lidar com uma realidade social muito distante das instâncias públicas.

A estratégia utilizada pela cultura jurídico-penal do período de criminalizar o aborto e adotar procedimentos policiais e judiciais para lidar com tal prática não surtiram os efeitos legais e sociais apregoados pelos operadores jurídicos que lutaram para tratar essa questão por meio de uma política criminal nos processos criminais que analisamos.

\section{Notas}

1 Código Penal de 1940 (Decreto-Lei $n^{\circ} 2.848$, de 7 de dezembro de 1940). 
2 Código Penal de 1940. Art. 124 - Provocar aborto em si mesma ou consentir que outrem lhe provoque. Art. 125 - Provocar aborto, sem consentimento da gestante. Art. 126 - Provocar aborto com o consentimento da gestante. Art. 127 - As penas cominadas nos dois artigos anteriores são aumentadas de um terço, se, em conseqüência do aborto ou dos meios empregados para provocá-lo, a gestante sofre lesão corporal de natureza grave; e são duplicadas, se, por qualquer dessas causas, lhe sobrevém a morte.

3 Código Penal de 1940. Art 128 - Não se pune o aborto praticado por médico: I - se não há outro meio de salvar a vida da gestante; II - se a gravidez resulta de estupro e o aborto é precedido de consentimento da gestante ou, quando incapaz, de seu representante legal.

4 Código Penal de 1890 (Decreto ${ }^{\circ} 847$, de 11 de outubro de 1890).

5 Reportagem na revista Época de 26 de abril de 2004: "O Prefeito da cidade de Goiás safou-se de uma pena de 10 anos e oito meses de prisão por estupro de sete meninas menores de 14 anos. O Tribunal de Goiás extinguiu a pena porque o Prefeito exibiu as sete certidões de casamento de suas vítimas.”

6 Código Penal de 1940. Art. 215 - Ter conjunção carnal com mulher honesta, mediante fraude: Pena - reclusão, de um a três anos; Art. 216 - Induzir mulher honesta, mediante fraude, a praticar ou permitir que com ela se pratique ato libidinoso diverso da conjunção carnal: Pena - reclusão, de um a dois anos.

Criminal justice and women's condition in Rio de Janeiro, Brazil, in the middle of the twentieth century

Abstract: A new juridical and penal order was implanted in Brazil in the beginning of the 1940's, during the Estado Novo, the political regime under Getúlio Vargas' government. Rio de Janeiro was the republic capital then. Abortion was classified as crime and prosecution legalism tried to convey litigious situations inside the courts. This article aims at analyzing how the judicial procedures, 
on which judiciary power denounced women for abortive practices, were conducted.

Keywords: juridical and penal culture, women's condition, abortion.

\section{Fontes primárias (autos criminais)}

Processo n ${ }^{0} 14 / 1944-11^{\text {a }}$ Vara Criminal - $1^{\circ}$ Tribunal do Júri.

Processo no $339 / 1957$ - 26 $6^{\text {a }}$ Vara Criminal - 2º Tribunal do Júri.

Processo $n^{\circ}$ 900/1959 - 26 $6^{\text {a }}$ Vara Criminal - 2º Tribunal do Júri.

Processo n ${ }^{\circ}$ 1732/ $1964-1^{\text {a }}$ Vara Criminal - $1^{\circ}$ Tribunal do Júri.

\section{Referências bibliográficas}

ADORNO, Sérgio. Discriminação racial e justiça criminal em São Paulo. Novos Estudos Cebrap, São Paulo, n. 43, p. 45-63, 1995.

. Crime, justiça penal e desigualdade jurídica - as mortes que se contam no Tribunal do Júri. Revista USP, São Paulo, n. 2, p. 132151, 1994.

. Os aprendizes do poder. Rio de Janeiro: Paz e Terra, 1988.

ALMEIDA JUNIOR, A. F. Aborto e infanticídio. Revista Forense, Rio de Janeiro, v. 91, p. 37-46, 1942.

ALVAREZ, Marcos César. A criminologia no Brasil ou como tratar desigualmente os desiguais. Dados, Rio de Janeiro, vol. 45, n. 4, p. 677-704, 2002.

ARIÈS, Philippe. História social da criança e da família. Rio de Janeiro: Zahar, 1978.

ARIÈS, Philippe; BÉJIN, André. Sexualidades ocidentais. São Paulo: Brasiliense, 1985. 
ASSIER-ANDRIEU, Louis. O direito nas sociedades humanas. São Paulo: Martins Fontes, 2000.

AURELIANO, João. Da aplicação concreta da pena - Artigos 42 e 50 do Código Penal. Revista Forense, Rio de Janeiro, v. 117, p. 348-355, 1948.

AZZI, Riolando. Família, mulher e sexualidade na Igreja do Brasil (19301964). In: MARCÍLIO, Maria Luiza (Org.). Familia, mulher, sexualidade e Igreja na história do Brasil. São Paulo: Loyola, 1993. p. 56-80.

BARATTA, Alessandro. Criminologia crítica e crítica do direito penal. Rio de Janeiro: Freitas Bastos, 1999.

BASSANEZI, Carla. Mulheres dos anos dourados. In: DEL PRIORI, Mary (Org.) História das mulheres no Brasil. São Paulo: Ed. Unesp, Contexto, 1997. p. 607-639.

BATISTA, Nilo. Matrizes ibéricas do sistema penal brasileiro - I. Rio de Janeiro: Freitas Bastos, 2000.

BENJAMIN, Walter. Crítica da violência: crítica do poder. In: BOLLE, W. (Org.). Documentos de cultura, documentos de barbárie. São Paulo: Cultrix; Edusp, 1986.

BLOCH, Marc. Apologia da história ou o oficio do historiador. Rio de Janeiro: Jorge Zahar, 2001.

BOURDIEU, Pierre. O poder simbólico. Lisboa: Difel, 1989.

BRUNDAGE, James. La ley, el sexo y la sociedad cristiana en la Europa medieval. México: Fondo de Cultura, 2000.

CALDEIRA, Tereza. Direitos humanos ou "privilégios de bandidos"? Novos Estudos Cebrap, São Paulo, n. 30, p. 162-173, 1991.

CARDIA, Nancy. Direitos humanos e exclusão moral. Sociedade e Estado, Brasília, v.10, n. 2, p. 343-389, 1995.

CAULFIELD, Sueann. "Que virgindade é esta?": a mulher moderna e a reforma do código penal no Rio de Janeiro, 1918 a 1940. Acervo, Rio de Janeiro, v. 9, n. 1-2, p. 165-202, 1996. 
CHARTIER, Roger. Diferenças entre os sexos e dominação simbólica: nota crítica. Cadernos Pagu, Campinas, n. 4, p. 37-47, 1995.

CÓDIGO Penal de 1940 - Decreto Lei 2848 de 07/12/1940. Acesso em: 1 de março de 2006. Disponível em: https://www.planalto.gov.br/ ccivil_03/decreto-lei/1937-1946/_quadro.htm>.

CORRÊA, Mariza. Morte em família. Rio de Janeiro: Graal, 1983. . Os crimes da paixão. São Paulo: Brasiliense, 1981.

FOUCAULT, Michel. A verdade e as formas jurídicas. Rio de Janeiro: Ed. Nau, 1996.

. Vigiar e punir. 9. ed. Petrópolis: Vozes, 1991.

GARCIA, Basileu. Influência dos motivos determinantes. Revista Forense, Rio de Janeiro, v. 93, p. 244-252, 1943.

GINZBURG, Carlo. Mitos, emblemas e sinais. São Paulo: Cia das Letras, 1989.

HESPANHA, Antonio Manuel. A história do direito na história social. Lisboa: Livros Horizonte, 1978.

HUNGRIA, Nelson. O código penal e as novas teorias criminológicas. Revista Forense, Rio de Janeiro, v. 91, p. 18-28, 1942.

. O direito penal no Estado Novo. Revista Forense, Rio de Janeiro, v. 85, p. $265-272,1941$.

. O crime de contágio venéreo. Revista Forense, Rio de Janeiro, v. 84, p. 276-285, 1940.

KALSING, Vera S. Schaefer. O debate do aborto: a votação do aborto legal no Rio Grande do Sul. Cadernos Pagu, Campinas, n. 19, p. 279-314, 2002.

LEGENDRE, Pierre. O amor do censor: ensaio sobre a ordem dogmática. Rio de Janeiro: Forense Universitária, 1983.

MAGALHÃES, Agamenon. O Estado e o direito. Revista Forense, Rio de Janeiro, v. 85, p. 403-403, 1941. 
MÉDICI FILHO, Atugasmin. O infanticídio no novo código penal. Revista dos Tribunais, v. 140, p. 357-370, 1942.

MELLO, João Manuel C.; NOVAIS, Fernando. Capitalismo tardio e sociabilidade moderna. In: SCHWARCZ, Lilia Moritz (Org. do volume). História da vida privada no Brasil: contrastes da intimidade. São Paulo: Cia das Letras, 2006. v. 4, p. 559-658.

NEDER, Gizlene. Discurso jurídico e ordem burguesa no Brasil. Porto Alegre, Sérgio Antonio Fabris, 1995.

. Ajustando o foco das lentes: um novo olhar sobre a organização das famílias no Brasil. In: KALOUSTIAN, Sílvio Manoug (Org.) Família brasileira: a base de tudo. 4. ed. São Paulo: Cortez; Brasília: Unicef, 1994. p. 26-46.

NEVES, Marcelo. A constitucionalização simbólica. São Paulo: Ed. Acadêmica, 1994.

OPOTOW, Susan. Moral exclusion and injustice: an introduction. Journal of Social Issues, v. 46 n.1, p. 1-20, 1990.

PANDOLFI, Dulce Chaves et al. (Orgs.) Cidadania, justiça e violência. Rio de Janeiro: Editora FGV, 1999.

PERROT, Michelle. Escrever uma história das mulheres: relato de uma experiência. Cadernos Pagu, Campinas, n. 4, p. 9-28, 1995.

PINHEIRO, Paulo Sérgio. Autoritarismo e transição. Revista USP, São Paulo, n. 9, p. 45-56, 1991.

PIO XI (Papa). Encíclica Casti Connubbi. 1930. Disponível em: http:// www.vatican.va/holy_father/pius_xi/encyclicals/index_po.htm>. Acesso em: 30 abr. 2005.

RAMÍREZ, Martha Célia. A propriedade do corpo: o lugar da diferença nos discursos de homens e mulheres acerca do aborto voluntário. Cadernos Pagu, Campinas, n. 15, p. 297-335, 2000.

RAUTER, Cristina. Criminologia e subjetividade no Brasil. Rio de Janeiro: Revan, 2003. 
RIBEIRO, Carlos Antonio Costa. As práticas judiciais e o significado do processo de julgamento. Revista Dados, Rio de Janeiro, v. 42, n. 4, p. 701-728, 1999.

RODRIGUES, Fabiana C. Malha. Os crimes das mulheres: aborto e infanticídio no direito na passagem à modernidade no Brasil, 18901916. Dissertação (Mestrado em História) - Universidade Federal Fluminense, Niterói, 2004.

ROLIM, Rivail Carvalho. As culturas jurídicas ocidentais e as idéias jurídico-penais no Brasil - décadas de 1930/40. Acta Scientiarum, Maringá, v. 27, n. 01, p. 47-59, 2005.

. O policiamento e a ordem: histórias da polícia em Londrina 1948-1962. Londrina: Eduel, 2005.

ROLIM, Rivail Carvalho. Os sentidos da desigualdade: uma história social da exclusão moral na cultura jurídico-penal brasileira - 1938/1964. Tese (Doutorado em História) - Universidade Federal Fluminense, Niterói, 2004.

ROMANO, Roberto. Brasil: Igreja contra Estado. São Paulo: Kairós, 1979.

RUSCHE, Georg; KIRCHHEIMER, Otto. Punição e estrutura social. Trad. Gizlene Neder. Rio de Janeiro: Revan, 2004.

STEVENSON, Oscar. Doutrina católica de Direito Penal. Revista Forense, Rio de Janeiro, v. 106, p. 13-28, 1946.

VIANNA, Luiz Werneck et al. Corpo e alma da magistratura brasileira. Rio de Janeiro: Revan,Iuperj, 1997.

ZAFFARONI, Eugenio Raúl. Em busca das penas perdidas: a perda da legitimidade do sistema penal. Rio de Janeiro: Revan, 2001. 